\title{
Nutritional status of pre-pregnant and pregnant women residing in Bogor district, Indonesia: a cross-sectional dietary and nutrient intake study
}

\author{
Siti Madanijah ${ }^{1,2}$, Dodik Briawan ${ }^{1,2}$, Rimbawan Rimbawan ${ }^{1,2}$, Zulaikhah Zulaikhah ${ }^{1}$, Nuri Andarwulan ${ }^{1,3}$, \\ Lilis Nuraida ${ }^{1,3}$, Tonny Sundjaya ${ }^{4}$, Laksmi Murti ${ }^{5}$, Priyali Shah ${ }^{6}$ and Jacques Bindels ${ }^{6 *}$ \\ ${ }^{1}$ SEAFAST Centre, Bogor Agricultural University, Kampus IPB Darmaga, Bogor 16680, Indonesia \\ ${ }^{2}$ Community Nutrition, Bogor Agricultural University, Bogor 16680, Indonesia \\ ${ }^{3}$ Food Science \& Technology, Bogor Agricultural University, Bogor 16680, Indonesia \\ ${ }^{4}$ Research \& Development, PT Saribusada Generasi Mahardhika, Jakarta 12950, Indonesia \\ ${ }^{5}$ Research \& Development, PT Nutricia Indonesia Sejabtera, Jakarta 13710, Indonesia \\ ${ }^{6}$ Nutricia Research, Danone Nutricia Early Life Nutrition, Singapore 138661, Singapore
}

(Submitted 25 September 2014 - Final revision received 8 December 2015 - Accepted 11 December 2015 - First published online 15 April 2016)

\section{Abstract}

The diet of Indonesian women of childbearing age is relatively poor, posing increased risk for suboptimal pregnancy outcome. In a cross-sectional study including 403 women in three economic quintiles (Q), we investigated differences in dietary intake and nutrition sufficiency according to economic status and whether regular dietary intakes of pregnant women (PW, $n$ 203) differ from that of pre-pregnant women (PPW, $n$ 200). Dietary intake data were collected using $2 \times 24 \mathrm{~h}$ dietary recall and FFQ. Energy, protein, Fe, Ca, Zn, vitamin A and vitamin C intakes were calculated utilising Food Composition Tables and compared with Indonesian recommendations for adequacy. Energy and protein intakes $<70 \%$ and $\mathrm{Fe}, \mathrm{Ca}, \mathrm{Zn}$, vitamin A and vitamin $\mathrm{C}$ intakes $<77 \%$ of the local recommendation were considered insufficient. A higher intake of milk/dairy products (Q3, Q4), fruits and vegetables (Q2) and snacks (Q3) in PW was observed compared with PPW, but insufficient to meet nutrient requirements. Nutrient intake calculations showed insufficiency in $26 \%$ of PPW for protein and up to $70 \%$ for Fe. Deficient nutrient intakes in PW were found in $49 \%$ of the subjects for energy and up to $85 \%$ for Fe. Energy and protein intakes decreased with decreasing economic quintiles in PPW and PW. Ca and vitamin A intakes were lower in Q2 compared with Q4. The proportion of animal protein in Q2-PW was low (31\%). Biochemical status parameters in a subset showed that anaemia and Fe and $\mathrm{Zn}$ deficiencies were prevalent among PPW and PW. Habitual diets in the study area did not meet the nutrient requirements for both PPW and PW across the investigated economic groups.

\section{Key words: Pregnant women: Pre-pregnant women: Food intakes: Nutrient intakes: Micronutrient intakes}

Maternal nutrition is a fundamental determinant of fetal growth, birth weight and infant morbidity; poor nutrition often leads to longterm, irreversible and detrimental consequences to the fetus ${ }^{(1)}$. Although government policies and programmes in Indonesia address nutrition among children ( $<5$ years) and pregnant women (PW), $12.3 \%$ of the Indonesian women are yet underweight ${ }^{(2)}$. The prevalence of anaemia and chronic energy deficiency in women (>15 years old) is 19.7 and $13.6 \%$, respectively ${ }^{(3)}$. Among Indonesian PW, anaemia and micronutrient deficiencies (folic acid, Zn, vitamin $A$, vitamin $B_{12}$ ) are quite high (40-50\%), which may lead to poor pregnancy outcomes. Earlier studies from Indonesia have shown an inadequate intake of food and several nutrients by $\mathrm{PW}^{(4-0)}$. Women are undernourished in the first trimester of the pregnancy and have an insufficient weight gain during pregnancy $(79 \%)^{(7)}$. Nutritional status during pregnancy not only puts the mother 'at risk' but is also a risk factor for the infant being born with low birth weight (LBW: 9-11\% in Indonesia) ${ }^{(8)}$.

There are limited recent data on the nutritional status of women of reproductive age in Indonesia. Thus, the aim of the present cross-sectional study conducted in Bogor municipality, West Java, Indonesia, was to obtain data on food patterns, nutrient intakes and nutritional status of pre-pregnant women (PPW) and PW and to investigate whether and to what extent they differ. The secondary aim was to compare the intakes of the women across different economic quintiles (Q).

\section{Methods}

The present cross-sectional study was conducted in the six sub-districts of Bogor city: north, west, south, east and central

Abbreviations: HHEQ, household expenditure quintile; MUAC, mid-upper-arm circumference; PPW, pre-pregnant women; PW, pregnant women; Q, quintiles.

* Corresponding author: Dr J. Bindels, email jacques.bindels@danone.com

Publication of these papers was supported by unrestricted educational grants from PT Sarihusada Generasi Mahardhika and PT Nutricia Indonesia Sejahtera. The papers included in this supplement were invited by the Guest Editors and have undergone the standard journal formal review process. They may be cited. The Guest Editors declare that there are no conflicts of interest. 
Bogor and Tanah Sareal. Ethics approval for the study was granted by the Health Research Institute at the Ministry of Health (No. LB.03.02/KE/6433/2010). The data were collected between January and May 2011 by study assistants with an educational qualification in community nutrition and previous experience in conducting nutritional surveys. They were further trained in the methods utilised in the present study.

Eligible PPW and PW were randomly selected from the records available at the participating integrated community services posts (Pos Pelayan Terpadu; POSYANDU) covering the various regions of Bogor district and contacted by study field workers, after having obtained permission from the respective public health centres (Pusat Kesehetan Masyarakat; PUSKESMAS) with equal representation out of the six sub-districts: west, north, south, east and central Bogor and Tanah Sareal. Non-PW in the age group of 20-40 years, not suffering from any chronic disease affecting their dietary intake pattern and without any acute morbidity condition on the day of survey, married and not committed to any form of family planning or aware of infertility were considered as women preparing for pregnancy and were recruited to the PPW group. Similarly, PW free from any disease either pregnancy related or non-pregnancy related with gestational age between 13 and $<28$ weeks were recruited to the PW group. The second trimester was preferred for our study as physiological changes are more pronounced compared with the first trimester and compliance to our protocol and procedures during the third trimester were expected to be less good. The household expenditure was used to obtain proxy information on the socio-economic status, thus classifying the women into their appropriate Bogor district household expenditure quintiles (HHEQ) ${ }^{(9)}$ : HHEQ-2: 250-330 000, HHEQ-3: 330-430 000 and HHEQ-4: 430-620 000 IDR/cap per month. These levels mainly cover the wider 'middle-income' group, representing $60 \%$ of the households in Bogor district: HHEQ-2, clearly lower middle income and HHEQ-4, clearly higher middle income. We did not study women in the lowest and in the highest quintiles of household expenditure, because in our pre-study we experienced a clearly lower willingness to comply with our protocol and procedures among these groups. Women qualifying for HHEQ-2-4 and meeting the inclusion/ exclusion criteria were enrolled for the study. A total of 221 PPW and $220 \mathrm{PW}$ were approached to obtain verbal consent to participate in the study. In all, 200 PPW and 203 PW participated in the study. In addition, written consent to have a blood sample drawn to assess biomarkers for micronutrient status was obtained from both forty-five PPW and PW equally divided into the three HHEQ.

A pre-tested semi-structured close-ended questionnaire was administered to each enrolled woman to obtain information on socio-demographic profile (age, education, occupation and family size), dietary intake and anthropometric profile.

Anthropometric measurements of mid-upper-arm circumference (MUAC) and weight from the participating PPW and PW were obtained by the study field workers using standard methodology ${ }^{(10)}$. We used a MUAC cut-off value of $<23.5 \mathrm{~cm}$ and maternal weight $<45 \mathrm{~kg}$ as risk indicators for poor pregnancy outcomes ${ }^{(11,12)}$.

A semi-quantitative FFQ was administered to assess the frequency and amount of intake of different food groups during the past 1 week. The frequency of consumption of foods from eight major food groups was collected: (1) cereal and cereal products; (2) meat/poultry and their products; (3) fish and fish products; (4) egg and egg products; (5) milk and dairy products; (6) legumes and their products; (7) vegetables and their products; and (8) fruits and their products. Indonesian women have a significant intake of intermittent snack foods. Thus, snacks and beverages were added to the list of the above-mentioned eight food groups.

Two daily dietary intake data sets were collected utilising the 24-h dietary recall method ${ }^{(10)}$. Intake was calculated using the food composition data from the Indonesian Food Composition Table (IFCT) (2004 and 2008) ${ }^{(13,14)}$ as a leading source. In case items not covered in the IFCT were consumed, other food composition databases such as NutriSurvey ${ }^{(15)}$ were used. Country-specific nutrient intakes issued in 2004 were considered as the reference recommendations ${ }^{(16)}$ for the study group. Women with energy and protein intakes $<70 \%$ of the recommended levels were classified as having clear deficient intakes $^{(17)}$. Women with micronutrient intakes ( $\mathrm{Fe}, \mathrm{Ca}, \mathrm{Zn}$, vitamin A, vitamin C) $<77 \%$ of the recommended levels as a proxy for estimated average requirements (EAR) were considered as having 'deficient intakes' ${ }^{,(10)}$. PW were also asked about their intake of supplements, but nutrient intakes from supplements were not included in our analysis.

Blood samples (10-12 ml) for biochemical analyses were obtained from a subset of women (forty-five PPW and PW each) to assess selected micronutrient status. Women were invited to the central laboratory Prodia, Bogor City, for drawing blood from the antecubital vein. Samples were stored at $-80^{\circ} \mathrm{C}$ until analysis. $\mathrm{Hb}$, serum ferritin, serum retinol and serum $\mathrm{Zn}$ levels were analysed using the cyanmethemoglobin method ${ }^{(18)}$, chemiluminescent immunoassay ${ }^{(19)}, \operatorname{HPLC}^{(20)}$ and atomic absorption spectrophotometry ${ }^{(21)}$, respectively. C-reactive protein (CRP) was measured using immunoturbidimetry, and was used as an indicator of inflammation. Ferritin values from samples with CRP $>5 \mathrm{mg} / \mathrm{l}$ were excluded from further analysis. Analysis was performed within 6 months of blood collection.

To detect a meaningful difference of about $20 \%$ in any nutrient deficiency, a typical sample size of 100 subjects/group is commonly used. Our comparison between total PPW and PW among all 200 subjects is clearly over-powered and using three individual HHEQ ( $n$ 65) may be somewhat under-powered, but still meaningful. Owing to wide variations in similar surveys, we considered it not to be very helpful to apply whatever formulas and choose rather arbitrary distribution characteristics. The number of forty-five PPW and PW for biochemical analysis reflected a practical limitation. We made sure that the three HHEQ were equally distributed among these women, but did not carry out a separate analysis. All the data were entered into a database and double-checked for any possible keyboard error. Data analysis was carried out using SPSS 17.0 for Windows. We used descriptive analysis (percentages, medians and interquartile ranges (IQR) of nutrients) on demographic characteristics including age, education level, household income, income per capita, family size, nutritional status, food consumption and nutrient intake. To compare food consumption and nutrient intakes between HHEQ, we first applied ANOVA testing and subsequently compared HHEQ-2 with HHEQ-4 using the Mann-Whitney test in non-normally 
distributed data sets and the $t$ test when both data sets were normally distributed. Medians and IQR levels were reported instead of mean values and standard deviations due to the wide variability and non-normal distributions in the data. Results were considered statistically significant at 5\% level of significance.

\section{Results}

All women had at least basic education. Most of the women (80\%) were housewives. All women, except one, had attended primary school with a higher percentage in HHEQ-4 having tertiary education. Education and family size distribution are given in Table 1. Other background variables such as occupation and education level of the husband, current minor health discomfort and recent infectious diseases were also recorded and provided a similar picture according to differences in socio-economic status. Almost 12.5 and $18.3 \%$ of the PPW and PW, respectively, were chronic-energy-deficient women based on MUAC $(<23.5 \mathrm{~cm})$. Weight measures revealed that 15.5 and $9.9 \%$ of PPW and PW weighed $<45 \mathrm{~kg}$, respectively, indicative of increased risk of LBW in Asian countries regardless of gestational age ${ }^{(12)}$. BMI among the PPW revealed that $14 \%$ of them were underweight (BMI $<18.5 \mathrm{~kg} / \mathrm{m}^{2}$ ), whereas $31 \%$ of them were overweight/ obese (BMI $>25.0 \mathrm{~kg} / \mathrm{m}^{2}$ ). As for many PW, we had no accurate record on pre-pregnancy weight; BMI was not calculated for PW (Table 1).

FFQ showed that cereals (mainly rice and their products) and beverages were consumed by all women across the HHEQ. Legumes, vegetables and fish consumption was an inherent part of the women's daily diet; overall $>70 \%$ consumed these foods and their products. Overall, more PW (57\%) consumed milk (and dairy products) as compared with the PPW (26\%). Similarly, more PW (40\%) consumed fruits as compared with the PPW (26\%). Consumption patterns of legumes and vegetables (and their products) were similar among the two groups of women, whereas consumption pattern of poultry showed higher values among PPW compared with PW (45 v. 35\%).

With respect to HHEQ, consumption pattern of poultry and milk showed an economic gradient. The consumption pattern of fruits was least frequent among women in the lowest HHEQ (both groups). Consumption pattern of fish decreased with increasing HHEQ among PW. Snacking was highly prevalent among both groups of women. Typically, for Indonesia, more than $80 \%$ of the women across all studied HHEQ consumed home-made and manufactured snack foods.

The total amount of food intake increased with increasing HHEQ. Cereals were the largest amount of solid food consumed by women. Comparing cereal intake, no significant difference was observed between PW and PPW despite the different physiological conditions $(P=0 \cdot 42)$. Median intake of milk was significantly higher among PW $(P=0 \cdot 01)$. Similarly, intakes of vegetables and fruits were greater among PW. Upon increasing HHEQ, PPW had a significant increase in cereals and meat/ poultry intakes $(P<0.05)$ and a trend for significance $(P=0.06)$ for increasing vegetable consumption. For PW, a significant increase upon HHEQ was found for milk and dairy products $(P<0.05)$ and a trend for meat/poultry, eggs and legumes $(P=0 \cdot 05-0 \cdot 10)$. These relationships according HHEQ for PPW and PW were confirmed by comparing HHEQ-2 with HHEQ-4. Overall, PW consumed more snack foods compared with PPW $(P<0.05)$, and the median amounts of snack food intake increased with increasing HHEQ (Table 2).

Median protein intake was similar in the two groups of women, whereas median energy intake was higher among the PW (significant only in HHEQ-2: $P<0.05$ ). Energy and protein intakes increased with economic gradient (Table 3). Almost half of the PW and $45 \%$ of the PPW were having inadequate energy intakes ( $<70 \%$ RDA) (Fig. 1). Overall, 24 and $44 \%$ of the PPW and PW, respectively, had combined deficiency of energy and protein (data not shown). Among PPW, there was no significant difference in energy intake between overweight/ obese PPW $\left(\mathrm{BMI} \geq 25.0 \mathrm{~kg} / \mathrm{m}^{2}\right) v$. normal BMI women (BMI $\left.18.5-<25.0 \mathrm{~kg} / \mathrm{m}^{2}\right)$. Protein quality in the current context is considered as the proportion of protein derived from animal foods. We found median proportions between 31 and $44 \%$ in the studied HHEQ of PW and PPW. Among PW (HHEQ-2), only $31 \%$ protein was derived from animal sources, and in PPW of HHEQ-2 and HHEQ-3 only 35 and $32 \%$ of protein was from animal sources (data not shown)

Overall, median intake of $\mathrm{Fe}$ and $\mathrm{Zn}$ was similar among the two groups of women. More than $80 \%$ of the PW were having an inadequate dietary Fe intake. Median dietary Zn intake among the PPW (except for HHEQ-2) showed that the intake was more than the recommendations. In PPW, there was a significant difference in Fe and $\mathrm{Zn}$ comparing HHEQ-2 with HHEQ-4 (Table 3). Ca intake was significantly higher among the PW $(P<0.05)$ and its intake showed an economic gradient in PPW $(P<0 \cdot 05)$. Upon comparing HHEQ-2 with HHEQ-4, a significantly higher intake was found in both Q4-PW and Q4-PPW $(P<0.05)$. In spite of this, overall 68 and $56 \%$ of the PPW and PW, respectively, were having inadequate dietary $\mathrm{Ca}$ intake $(P<0.05)$. Intakes of vitamin $\mathrm{A}$ and vitamin $\mathrm{C}$ were significantly higher among the PW as compared with the PPW $(P<0 \cdot 05)$. In PPW, both vitamin A and vitamin $\mathrm{C}$ were significantly higher in HHEQ-4 compared with HHEQ-2 and in PW this was only the case for vitamin A. Nevertheless, overall $>60$ and $>80 \%$ of the women (PW and PPW) were having vitamin A and vitamin C deficiency, respectively (Fig. 1). Supplement intake data showed that 45 and $19 \%$ of PW consumed $\mathrm{Fe}$ or multi-vitamin supplements, respectively. For PPW, 10 and $2 \%$ of the subjects reported intake of these supplements, respectively.

Prevalence of anaemia, Fe deficiency, $\mathrm{Zn}$ deficiency and vitamin A deficiency in a subset of the respondents is given in Table 4. Particularly, Fe and Zn deficiency were widely prevalent. Owing to the limited sample size, differences among the two groups of women were not statistically significant $(P>0.05$; data considered as categorical and tested according to $\chi^{2}$ method).

\section{Discussion}

The present study reports on the nutritional status of women of reproductive age as per anthropometric measurements, dietary intake and biochemical parameters (in a subset of women). At least $10 \%$ of the women are likely to initiate their pregnancy 
Table 1. Background characteristics and the anthropometric profile of enrolled study subjects (Numbers and percentages; medians and interquartile ranges (IQR))

\begin{tabular}{|c|c|c|c|c|c|c|c|c|c|c|c|c|}
\hline \multirow[b]{3}{*}{ Parameters } & \multicolumn{4}{|c|}{ Q2 } & \multicolumn{4}{|c|}{ Q3 } & \multicolumn{4}{|c|}{ Q4 } \\
\hline & \multicolumn{2}{|c|}{ PPW $(n 66)$} & \multicolumn{2}{|c|}{$\mathrm{PW}(n$ 68) } & \multicolumn{2}{|c|}{ PPW ( $n$ 65) } & \multicolumn{2}{|c|}{$\mathrm{PW}(n$ 67) } & \multicolumn{2}{|c|}{ PPW ( $n$ 69) } & \multicolumn{2}{|c|}{$\mathrm{PW}(n$ 68) } \\
\hline & $n$ & $\%$ & $n$ & $\%$ & $n$ & $\%$ & $n$ & $\%$ & $n$ & $\%$ & $n$ & $\%$ \\
\hline \multicolumn{13}{|l|}{ Age (years) } \\
\hline Median & \multirow{2}{*}{\multicolumn{2}{|c|}{$\begin{array}{c}30 \cdot 0 \\
26 \cdot 8 ; 34 \cdot 0\end{array}$}} & \multirow{2}{*}{\multicolumn{2}{|c|}{$\begin{array}{c}30 \cdot 0 \\
26 \cdot 0 ; 32 \cdot 0\end{array}$}} & & & \multirow{2}{*}{\multicolumn{2}{|c|}{$\begin{array}{c}28 \cdot 0 \\
24 \cdot 0 ; 34.0\end{array}$}} & \multirow{2}{*}{\multicolumn{2}{|c|}{$\begin{array}{c}28 \cdot 0 \\
26 \cdot 0 ; 31 \cdot 0\end{array}$}} & \multirow{2}{*}{\multicolumn{2}{|c|}{$\begin{array}{c}26 \cdot 0 \\
23 \cdot 0 ; 31 \cdot 8\end{array}$}} \\
\hline IQR & & & & & & & & & & & & \\
\hline \multicolumn{13}{|l|}{ Education } \\
\hline Primary.school & 33 & $50 \cdot 0$ & 29 & $42 \cdot 7$ & 22 & 33.8 & 16 & 23.9 & 11 & $15 \cdot 9$ & 14 & 20.6 \\
\hline Junior high & 15 & $22 \cdot 7$ & 26 & $38 \cdot 2$ & 19 & $29 \cdot 2$ & 17 & $25 \cdot 4$ & 14 & $20 \cdot 3$ & 21 & 30.9 \\
\hline Higher education & 18 & $27 \cdot 3$ & 13 & $19 \cdot 1$ & 23 & $35 \cdot 4$ & 34 & 50.7 & 44 & 63.8 & 33 & 48.5 \\
\hline \multicolumn{13}{|l|}{ Family size } \\
\hline Small $(\leq 4)$ & 46 & 69.7 & 34 & $50 \cdot 0$ & 51 & 78.5 & 42 & $62 \cdot 7$ & 57 & $82 \cdot 6$ & 50 & 73.5 \\
\hline Moderate (5-7) & 20 & $30 \cdot 3$ & 28 & $41 \cdot 2$ & 14 & 21.5 & 24 & $35 \cdot 8$ & 11 & $15 \cdot 9$ & 15 & $22 \cdot 1$ \\
\hline $\operatorname{Big}(\geq 8)$ & \multicolumn{2}{|c|}{0} & 6 & 8.8 & \multicolumn{2}{|c|}{0} & 1 & 1.5 & 1 & 1.5 & 3 & 4.4 \\
\hline \multicolumn{13}{|l|}{ Weight (kg) } \\
\hline Median & \multirow{2}{*}{\multicolumn{2}{|c|}{$\begin{array}{c}54 \cdot 0 \\
48 \cdot 0 ; 61 \cdot 0\end{array}$}} & \multirow{2}{*}{\multicolumn{2}{|c|}{$\begin{array}{c}50 \cdot 3 \\
46 \cdot 3 ; 60.0\end{array}$}} & \multirow{2}{*}{\multicolumn{2}{|c|}{$\begin{array}{c}52 \cdot 0 \\
47 \cdot 0 ; 60 \cdot 3\end{array}$}} & \multirow{2}{*}{\multicolumn{2}{|c|}{$\begin{array}{c}54 \cdot 0 \\
49 \cdot 0 ; 62 \cdot 0\end{array}$}} & \multirow{2}{*}{\multicolumn{2}{|c|}{$\begin{array}{c}50 \cdot 0 \\
45 \cdot 8 ; 59.5\end{array}$}} & \multirow{2}{*}{\multicolumn{2}{|c|}{$\begin{array}{c}52 \cdot 5 \\
48 \cdot 3 ; 59 \cdot 8\end{array}$}} \\
\hline IQR & & & & & & & & & & & & \\
\hline Weight $<45 \mathrm{~kg}$ & 11 & $16 \cdot 7$ & 9 & $13 \cdot 2$ & 9 & 13.8 & 4 & 6.1 & 11 & $15 \cdot 9$ & 7 & $10 \cdot 3$ \\
\hline Height $(\mathrm{cm})$ & & & & & & & & & & & & \\
\hline Median & & & & & & & & & & & & \\
\hline IQR & & & & & & & & & & & & \\
\hline BMI $\left(\mathrm{kg} / \mathrm{m}^{2}\right)$ & & & & & & & & & & & & \\
\hline Median & & & & & & & & & & & & \\
\hline IQR & & & & & & & & & & & & \\
\hline BMI classes & & & & & & & & & & & & \\
\hline$<18.5 \mathrm{~kg} / \mathrm{m}^{2}$ & 9 & $13 \cdot 6$ & & & 6 & $9 \cdot 2$ & & & 11 & $15 \cdot 9$ & & \\
\hline $18.5-25.0 \mathrm{~kg} / \mathrm{m}^{2}$ & 37 & $56 \cdot 1$ & & & 38 & 58.5 & & & 37 & 53.6 & & \\
\hline$\geq 25.0 \mathrm{~kg} / \mathrm{m}^{2}$ & 20 & $30 \cdot 3$ & & & 21 & $32 \cdot 3$ & & & 21 & $30 \cdot 4$ & & \\
\hline $\operatorname{MUAC}(\mathrm{cm})$ & & & & & & & & & & & & \\
\hline Median & & & & & & & & & & & & \\
\hline IQR & & & & & & & & & & & & \\
\hline MUAC $<23.5$ & 9 & $13 \cdot 6$ & 12 & $17 \cdot 9$ & 7 & $10 \cdot 8$ & 14 & 20.9 & 9 & $13 \cdot 0$ & 11 & $16 \cdot 2$ \\
\hline
\end{tabular}

Q, quintiles; PPW, pre-pregnant women; PW, pregnant women; MUAC, mid-upper-arm circumference. 
Table 2. Daily intake of different food groups $(\mathrm{g})$ by women across socio-economic layers (Medians and interquartile ranges (IQR))

\begin{tabular}{|c|c|c|c|c|c|c|c|c|c|c|c|c|}
\hline \multirow[b]{3}{*}{ Food groups } & \multicolumn{4}{|c|}{ Intakes (HHEQ-2) } & \multicolumn{4}{|c|}{ Intakes (HHEQ-3) } & \multicolumn{4}{|c|}{ Intakes (HHEQ-4) } \\
\hline & \multicolumn{2}{|c|}{ PPW } & \multicolumn{2}{|c|}{ PW } & \multicolumn{2}{|c|}{ PPW } & \multicolumn{2}{|c|}{ PW } & \multicolumn{2}{|c|}{ PPW } & \multicolumn{2}{|c|}{ PW } \\
\hline & Median & IQR & Median & IQR & Median & IQR & Median & IQR & Median & IQR & Median & IQR \\
\hline Cereals and products & 451 & $320 ; 533$ & 471 & $301 ; 610$ & 523 & $358 ; 678$ & 477 & $331 ; 600$ & $504^{*} \dagger$ & $399 ; 655$ & 508 & $340 ; 638$ \\
\hline Meat/poultry and products & 45 & $30 ; 98$ & 69 & $46 ; 94$ & 69 & $45 ; 107$ & 58 & $27 ; 115$ & $90 * \ddagger$ & $45 ; 149$ & 75 & $45 ; 117$ \\
\hline Fish and products & 24 & $13 ; 33$ & 26 & $14 ; 35$ & 26 & $13 ; 34$ & 30 & $12 ; 15$ & 26 & $13 ; 47$ & 26 & $9 ; 41$ \\
\hline Egg and products & 39 & 22; 58 & 33 & 22; 50 & 34 & 22; 52 & 39 & 22; 47 & 39 & $28 ; 50$ & 40 & $22 ; 77$ \\
\hline Milk and dairy products & 240 & $121 ; 242$ & 242 & $120 ; 351$ & 174 & $121 ; 279$ & $248 \S$ & $239 ; 478$ & 242 & $149 ; 257$ & $424^{\star} \S \ddagger$ & $239 ; 478$ \\
\hline Legumes and products & 78 & $39 ; 101$ & 94 & $44 ; 151$ & 78 & $42 ; 122$ & 69 & $39 ; 108$ & 59 & $39 ; 102$ & 77 & 39; 137 \\
\hline Vegetables and products & 97 & $48 ; 176$ & $144 \S$ & $75 ; 250$ & 145 & $93 ; 250$ & 150 & $80 ; 254$ & $136 \ddagger$ & $79 ; 237$ & 142 & $89 ; 286$ \\
\hline Fruits and products & 80 & $47 ; 108$ & $100 \S$ & $84 ; 215$ & 75 & $47 ; 86$ & 96 & $57 ; 159$ & 95 & $47 ; 270$ & 112 & $84 ; 226$ \\
\hline Beverage & 1090 & $894 ; 1444$ & 1150 & $800 ; 1575$ & 1000 & $750 ; 1296$ & 1200 & $800 ; 1600$ & 1000 & $850 ; 1371$ & 1100 & $850 ; 1354$ \\
\hline Snack foods & 79 & $30 ; 118$ & 78 & $30 ; 161$ & 62 & $39 ; 111$ & $96 \S$ & $46 ; 159$ & 75 & $40 ; 134$ & 104 & $47 ; 174$ \\
\hline
\end{tabular}

HHEQ, household expenditure quintiles; PPW, pre-pregnant women; PW, pregnant women.

* Statistically significant trend according to HHEQ $(P<0.05)$ using ANOVA test.

† Statistically different between Q2 and Q4 $(P<0.05)$ using $t$ test.

‡ Statistically different between Q2 and Q4 $(P<0.05)$ using Mann-Whitney test.

$\S$ Statistically different between PPW and PW $(P<0.05)$ using Mann-Whitney test.

Table 3. Nutrient intakes of pregnant (PW) and pre-pregnant women (PPW)

(Medians and interquartile ranges (IQR))

\begin{tabular}{|c|c|c|c|c|c|c|c|c|c|c|c|c|c|}
\hline \multirow[b]{3}{*}{ Nutrients } & \multirow[b]{3}{*}{ AKG (PPW/PW) } & \multicolumn{4}{|c|}{ Intakes (HHEQ-2) } & \multicolumn{4}{|c|}{ Intakes (HHEQ-3) } & \multicolumn{4}{|c|}{ Intakes (HHEQ-4) } \\
\hline & & \multicolumn{2}{|c|}{ PPW } & \multicolumn{2}{|c|}{ PW } & \multicolumn{2}{|c|}{ PPW } & \multicolumn{2}{|c|}{ PW } & \multicolumn{2}{|c|}{ PPW } & \multicolumn{2}{|c|}{ PW } \\
\hline & & Median & IQR & Median & IQR & Median & IQR & Median & IQR & Median & IQR & Median & IQR \\
\hline Energy $(\mathrm{kJ})^{\star}$ & $7531-7949 / 8786-9205$ & 5125 & $4196 ; 6288$ & $6054 \dagger$ & $4301 ; 7665$ & 5636 & $4443 ; 6975$ & 6201 & $4845 ; 8092$ & $6556 \neq \S$ & $5113 ; 8146$ & $7021 \ddagger \|$ & $5749 ; 8552$ \\
\hline Energy (kcal) & $1800-1900 / 2100-2200$ & 1225 & $1003 ; 1503$ & 1447 & $1028 ; 1832$ & 1347 & $1062 ; 1667$ & 1482 & $1158 ; 1934$ & 1567 & $1222 ; 1947$ & 1678 & $1374 ; 2044$ \\
\hline Protein $(g)$ & $50 / 67$ & 38 & $32 ; 44$ & 37 & 28; 52 & 43 & $34 ; 56$ & 44 & $31 ; 56$ & $52 \ddagger \|$ & $39 ; 64$ & $50 \ddagger \|$ & 36; 68 \\
\hline $\mathrm{Fe}(\mathrm{mg})$ & $26 / 35$ & 15 & $11 ; 19$ & 15 & $11 ; 24$ & 16 & $13 ; 21$ & 16 & $10 ; 22$ & $17 \|$ & $12 ; 24$ & 15 & $10 ; 22$ \\
\hline $\mathrm{Ca}(\mathrm{mg})$ & $800 / 950$ & 453 & $254 ; 574$ & $606 \pi$ & $326 ; 788$ & 485 & $362 ; 733$ & 610 & $361 ; 1042$ & $587 \ddagger \|$ & $346 ; 942$ & 869ף॥ & $662 ; 1242$ \\
\hline $\mathrm{Zn}(\mathrm{mg})^{\star}$ & $9 \cdot 3-9 \cdot 8 / 13 \cdot 5-14 \cdot 0$ & 9 & $5 ; 13$ & 10 & $6 ; 17$ & 11 & $8 ; 16$ & 10 & $8 ; 14$ & $11 \|$ & 7; 17 & 11 & $8 ; 18$ \\
\hline Vitamin A (RE) & $500 / 800$ & 207 & $66 ; 410$ & 3709 & $148 ; 638$ & 216 & $66 ; 528$ & 519.0 - & $118 ; 745$ & $438 \|$ & $185 ; 738$ & $538 \|$ & $338 ; 859$ \\
\hline Vitamin C (mg) & $75 / 85$ & 8 & $3 ; 19$ & 13 & $5 ; 44$ & 12 & $3 ; 38$ & 20 & $9 ; 48$ & $14 \|$ & 8; 39 & 22 & $10 ; 40$ \\
\hline
\end{tabular}

AKG, Angka Kecukupan Gizi - Country-Specific Nutrient Recommendations for Indonesia; HHEQ, household expenditure quintiles; RE, retinol equivalents

* Requirements for energy and $\mathrm{Zn}$ are age specific.

† Statistically different between PPW and PW $(P<0.05)$ using $t$ test.

₹ Statistically significant trend according to HHEQ $(P<0.05)$ using ANOVA test.

$\S$ Statistically different between Q2 and Q4 $(P<0.05)$ using $t$ test.

II Statistically different between Q2 and Q4 $(P<0.05)$ using Mann-Whitney test.

I Statistically different between PPW and PW $(P<0.05)$ using Mann-Whitney test. 

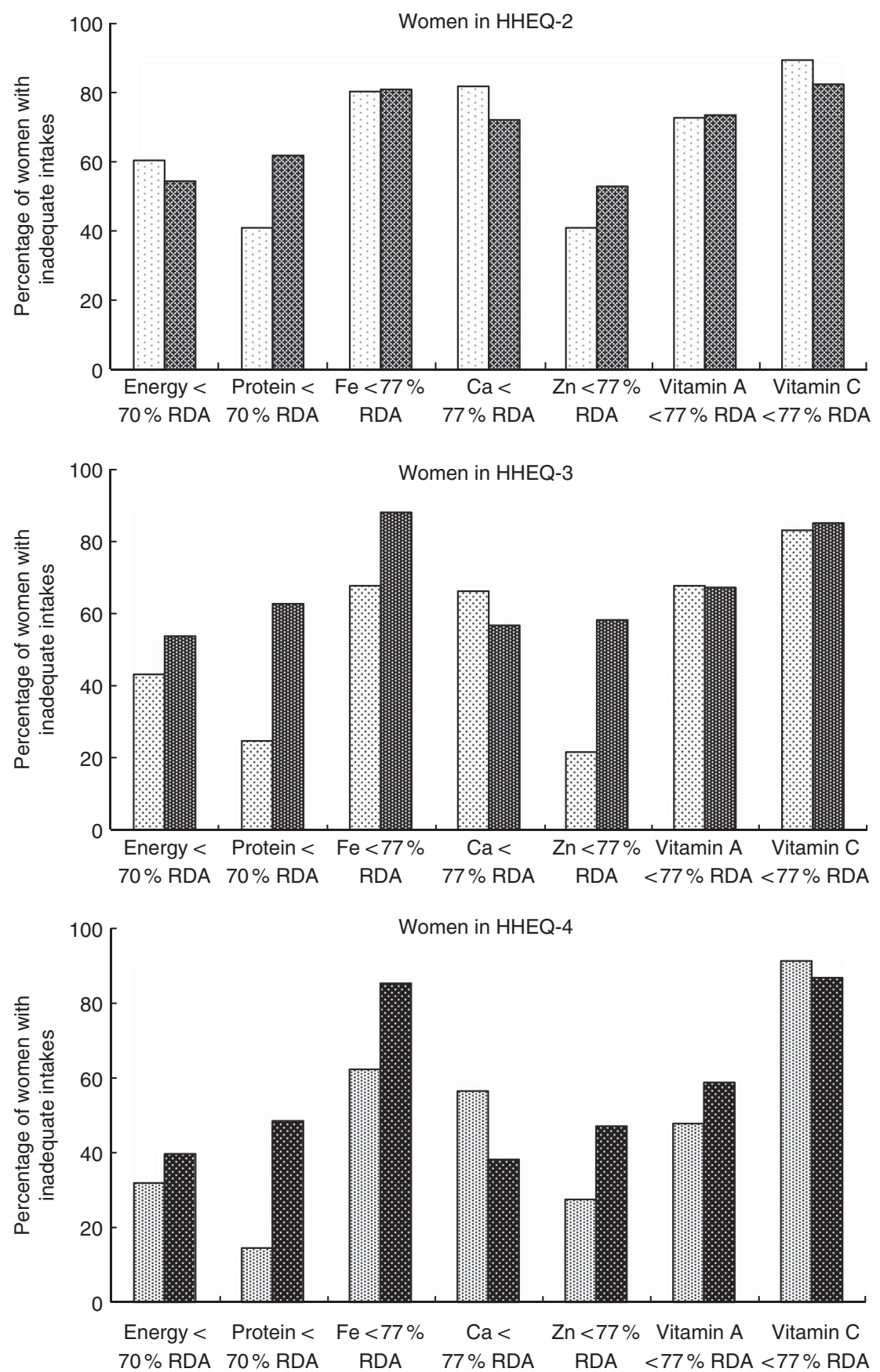

Fig. 1. Nutrient deficiencies among women enrolled in the study according to household expenditure quintile (HHEQ). Cut-off point $70 \%$ RDA for energy and protein according to Ministry of Health (Indonesia) ${ }^{(17)}$; cut-off point $77 \%$ RDA for micronutrients according to estimated average requirement estimate ${ }^{(10)}$. $\square$, Pre-pregnant women; 瞒, pregnant women.

Table 4. Biochemical analysis of blood samples collected (pre-pregnant women (PPW): $n$ 45; pregnant women (PW): $n$ 45)

\begin{tabular}{lcccc}
\hline Parameters (indicators) & PPW cut-off & PPW (prevalence (\%)) & PW cut-off & PW (prevalence (\%)) \\
\hline Anaemia (Hb level) & $<120 \mathrm{~g} / \mathrm{l}$ & 11.1 & $<110 \mathrm{~g} / \mathrm{l}$ & 22.2 \\
Fe deficiency (serum ferritin) & $<15 \mu \mathrm{g} / \mathrm{l}$ & 23.1 & $<15 \mu \mathrm{g} / \mathrm{l}$ & 41.2 \\
Vitamin A deficiency (serum retinol) & $<0.70 \mathrm{mmol} / \mathrm{l}$ & 6.7 & $<0.70 \mathrm{mmol} / \mathrm{l}$ & 13.3 \\
Zn deficiency (plasma Zn) & $<65 \mu \mathrm{mol} / \mathrm{l}$ & 42.2 & $<65 \mu \mathrm{mol} / /$ & 55.6 \\
\hline
\end{tabular}

* For serum ferritin determination, $n 39$ for PPW and $n 34$ for PW. 
with poor health status. MUAC measurement is a good indicator of the protein reserves in a body, and a thinner arm reflects wasted lean mass, that is malnutrition ${ }^{(22)}$. MUAC measures $<23.5 \mathrm{~cm}$ among Indonesian PW have been associated with risk of LBW as well as pre-term births ${ }^{(11)}$. A study in Bogor district showed a poor nutritional status as per MUAC measurements among PW with poor socio-economic status ${ }^{(23)}$. Maternal weight of $<45 \mathrm{~kg}$ in the second trimester among Indian populations has shown more than a 2-fold risk for $\mathrm{LBW}^{(24)}$. The gross agreement except for PW-Q3 in the proportion of women with either MUAC $<23.5 \mathrm{~cm}, \mathrm{BMI}<18.5 \mathrm{~kg} / \mathrm{m}^{2}$ or weight $<45 \mathrm{~kg}$ as a risk parameter for poor pregnancy outcome is interesting as there is no guidance on different cut-offs for maternal weight before and during pregnancy. As per BMI, nearly half (44\%) of the PPW in our study population were either underweight (13\%) or overweight $(31 \%)$, indicating that these women initiate their pregnancy without an optimal weight status and are possibly not ready to fully cope with the physiological changes during pregnancy.

In a post hoc sub-group analysis among PPW to investigate whether there are differences in nutrient intakes of overweight + obese women $\left(\mathrm{BMI}>25 \mathrm{~kg} / \mathrm{m}^{2}\right)$ and women with normal BMI $\left(18.5-25 \mathrm{~kg} / \mathrm{m}^{2}\right)$, we found statistical significances $(P<0.05$, according to $t$ test or Mann-Whitney test based on normal/ non-normal distribution) in four among twenty-eight possible comparisons (seven nutrients, three economic quintiles + total group), all of which indicated lower intake in the overweight + obese sub-group compared with the normal BMI sub-group. We are, however, reluctant to conclude that there may be a tendency among overweight + obese women to actually consume less of the specific nutrients including energy, but would rather attribute this finding to a tendency for under-reporting, especially by overweight and obese subjects as reported from various studies $^{(25-27)}$.

Earlier studies from Indonesia have already reported that PW subsist on plant foods, mainly based on rice, pulses, nuts and vegetables. Studies from other countries also have reported PW diet to be dominated by cereals and cereal products ${ }^{(28,29)}$. Intake of animal foods such as meat and chicken decreased with the increasing costs, and thus we observed the lowest intake in the lowest HHEQ for PPW and PW. Earlier studies from Indonesia have reported similar inadequate food intake mainly due to the socio-economic factor ${ }^{(30)}$. Our study confirms that there is still an economic gradient to meat consumption in PPW. Interestingly, the same holds true for vegetables intake, which are more expensive than staple foods in our studied urban area. Milk consumption in PW was higher compared with PPW across all HHEQ, indicating milk to be considered a nutritious food for PW. An earlier study showed that milk intake during pregnancy was associated with a reduced risk of small-for-gestational age, an increased risk of largefor-gestational age and an increased mean birth weight, abdominal circumference, placental weight, birth length and head circumference adjusted for gestational age at birth ${ }^{(31)}$. Typical for Indonesia, food consumed between main meals (snacking) was also common among the women of the present study contributing to their daily energy intake; however, as many snack foods are deep fried, they may not be the optimal choice ${ }^{(32)}$. Because of the high energy density of several deep-fried snack foods, the contribution of snack foods is substantial and simply recommending to abstain from these foods would aggravate the energy deficiency. Nevertheless, good, nutritious, low-cost, non-fried but still energy-dense snack foods rich in/or fortified with adequate nutrients are needed to improve the nutritional status of women in this region.

Nutrient intake data showed that at least half of the women (PPW and PW), with their habitual diet, across the studied HHEQ could not meet their nutrient requirements. A recent review of various studies conducted among Indonesian PW confirms that women do not change their dietary intakes on becoming pregnant and are not able to meet their EAR for several nutrients ${ }^{(4)}$. Increasing HHEQ showed increase in the energy and protein intakes, but not enough to meet adequacy, similar to another study ${ }^{(33)}$. Inadequate energy intake is indicative of an overall low intake of food. It is remarkable and possibly a paradox to observe a clear energy deficiency $(<70 \%$ RDA) in 32-60\% of PPW, whereas in this group 31\% were overweight or obese as well. We have no clear explanation for this except for the fact that physical activity may be far lower in our group than what is considered typical in establishing RDA. Another reason might be that we witnessed the consequence of differences in food availability in early life of the PW, making them especially vulnerable for obesity. Protein intake as \%RDA among the PW was less as compared with the PPW. Low protein intake is associated with poor pregnancy outcomes. Explicit recommendations regarding the minimal or optimal proportion of animal protein are lacking, but a recent review has suggested that about one-third of protein intakes should come from animal-source foods to make a significant impact on growth $^{(34)}$. Although these recommendations are for young children, we consider them relevant for women of reproductive age as well, especially PW. Thus, the median proportion of $31 \%$ animal protein intake in HHEQ-2 among PW, together with a total protein intake of only $55 \%$ of Indonesian RDA, increases the level of concern.

The majority of the women had dietary Fe deficiency similar to earlier findings ${ }^{(35,36)}$. Although Indonesia has an Fe supplementation programme in place for PW, compliance and possibly execution is suboptimal. One study reported that $85 \%$ of PW receive Fe supplements ${ }^{(35)}$, and in our study only $45 \%$ of the PW indicated actual consumption of the $\mathrm{Fe}+$ folic acid supplement. We did not take the Fe supplements into account in the dietary intake analysis. Among PW, 22\% were found to be anaemic and $41 \%$ showed Fe deficiency based on serum ferritin levels, with limited overlap, indicating that in $>50 \%$ of PW at least one indicator was affected. $\mathrm{Zn}$ is necessary for normal growth and development of the fetus and placenta, deficiency of which may cause intra-uterine growth retardation $^{(37)}$. Animal foods are good sources of $\mathrm{Zn}$; however, these were less frequently consumed by the study group. A recent study showed that dietary $\mathrm{Zn}$ intake from animal food sources and their proportions relative to total $\mathrm{Zn}$ intake were positively associated with birth weight and height. Conversely, the percentage of $\mathrm{Zn}$ intake from plant food sources relative to total $\mathrm{Zn}$ intake was negatively associated with birth height, indicating 
not only the amount of dietary $\mathrm{Zn}$ intake to be important but also the source of dietary $\mathrm{Zn}$ to be equally important ${ }^{(38)}$. The main food consumed by our population was cereals (rice) with little animal foods, posing a risk for poor fetal outcome. This is supported by the proportions of 42 and $56 \%$ of PPW and PW, respectively, with plasma $\mathrm{Zn}$ below healthy reference values.

$\mathrm{Ca}$ is required for bone formation, muscle contraction, and enzyme and hormone functioning ${ }^{(39)}$. Women with clearly suboptimal amounts of Ca intake $(<500 \mathrm{mg} / \mathrm{d})$ may be at risk for bone loss during pregnancy and may not meet fetal bone requirements ${ }^{(40)}$. On the basis of our results, this is the case in $>25 \%$ of HHEQ-2/HHEQ-3 PW. In spite of an increased intake of milk (source of Ca), half of the PPW as well as PW were not able to meet the dietary requirements for Ca across HHEQ, also indicated in other studies ${ }^{(35,36,41)}$.

Poor vitamin A intake has effects on fetal development and child health, for example, increased risk of pre-term birth, reduced intra-uterine growth, decreased birth weight and reduced vitamin A content in breast milk $^{(5)}$. Vitamin $\mathrm{C}$ cannot be synthesised or stored in the human body, and thus a daily supply is required for collagen synthesis and for increasing non-haem Fe absorption. Maternal vitamin C levels decrease during pregnancy, whereas in the fetal blood at delivery the levels are two to four times higher than in maternal blood ${ }^{(37)}$. Women in our study had deficient intakes of these vitamins, suggesting initiation of pregnancy with poor stores that possibly worsen during pregnancy and may result in inadequate fetal levels. The deficient vitamin A and $\mathrm{C}$ intakes were mainly driven by low vegetable and fruit consumption illustrated by our finding that only $<35$ and $<45 \%$ of the PPW and PW, respectively, reported any consumption of fruits. It is interesting to note that other studies from Indonesia show average intakes of vitamins $\mathrm{A}$ and $\mathrm{C}$ above $100 \%$ of $\mathrm{EAR}^{(36,42)}$, although Prihartini et $a l^{(6)}$ also reported from their Lombok study mean vitamin $\mathrm{C}$ levels well below EAR. These studies are older studies and may not be similar to the current dietary intake pattern of the women. Study area, method of assessment and inclusionexclusion criteria in those studies were different from the current study, thus possibly affecting the study results.

The cross-sectional design with reasonable number of subjects well distributed among the broad middle-class household expenditure covering three of the five HHEQ in a well-defined area is a major strength of the present study as most other studies do not focus on socio-economic status. The sample size of sixty-five to sixty-nine subjects per HQ for each group may be slightly under-powered, considering a typical sample size of about 100 subjects/group to be sufficient to detect a $20 \%$ difference in any nutrient deficiency. Because of the crosssectional design, our study provides no direct evidence about changing diet from pre-pregnancy to pregnancy as only a longitudinal study will be able to prove this. Nevertheless, we have no indications for severe dissimilarities in measured background variables, and thus conclude that both populations are sufficiently similar. We studied PW only in their second trimester of pregnancy, but from the results of the much larger Supplementation with Multiple Micronutrients Intervention Trial (SUMMIT) study ${ }^{(6)}$ in Lombok it may be inferred that major nutrient intakes and their deficiencies during the three trimesters of pregnancy are very similar if extrapolation to West Java is acceptable. Unfortunately, nutrient intake information for several other relevant nutrients (e.g. dietary fibre, fat quality, DHA, Se) could not be calculated in this study due to limited database in the currently available country-specific Food Composition Tables. Information on the quantitative intake of supplements by the women is limiting. The non-normal distribution of several variables presented a challenge for statistical analysis. We therefore used medians and IQR all over this report. Testing for the socio-economic gradient among the study's HHEQ was carried out by ANOVA, realising that this may not be fully appropriate with non-normally distributed variables. Therefore, post hoc tests were also used, comparing HHEQ-2 with HHEQ-4, using MannWhitney tests if needed. Any specific correction for subject under- and over-reporting was not carried out; however, because of non-normal distribution of many variables, we think that providing only the medians and the 25 th and 75 th percentiles is an acceptable approach. For energy intake, actual intakes may be compared with predicted total energy expenditure (pTEE) and reported values $<2$ SD would surely not be plausible ${ }^{(43)}$. For typical PPW in our study, 30 years of age, weight $50 \mathrm{~kg}$ and height $150 \mathrm{~cm}$, the $-2 \mathrm{sD}$ cut-off for pTEE amounts to $3950 \mathrm{~kJ}$ (944 kcal). Thus, we have reasonable confidence that reported energy intakes upwards from $4196 \mathrm{~kJ}$ (1003 kcal) (the 25th percentile for Q2-PPW) should not be rejected because of physiological incompatibility. Biochemical estimations could be performed for only a limited number of women because of both study logistics and cultural reasons among the women. Despite of this, there is reasonable agreement between both approaches, indicating little selection bias, if any.

\section{Conclusion}

Our study shows that at least half of the women of reproductive age (PPW and PW), with their habitual diets and irrespective of their income-expenditure status, are not able to meet the country-specific nutrient recommendations. As per the MUAC measurements, more than one in ten women initiate their pregnancy being chronically energy deficient, and the situation worsens to almost one in five during pregnancy. PW reported higher food intakes during pregnancy compared with PPW, and yet the extent of this higher intake was not enough to even meet the additional requirements defined by the Indonesian RDA for PW compared with non-PW. In 24 and $44 \%$ of the PPW and PW, respectively, a combined inadequate intake of energy and protein was found. Improving food quantity and quality to increase intake of specific macro- and micronutrients, possibly through food fortification, is recommended, even though affordability/poverty may still be an issue in the lowest income-expenditure quintile. Clearly, more nutrition education is needed across all socio-economic classes to increase understanding of nutrient requirements during this specific stage in life.

\section{Acknowledgements}

The authors are extremely grateful to all the pre-pregnant and pregnant women and their families for their willingness to 
participate in the present study. The authors thank the women volunteers (kaders) and enumerators for their contribution during the data collection; and to the government and health representatives at all levels for their contribution to the study. The authors also thank PT Sarihusada Generasi Mahardhika and PT Nutricia Indonesia Sejahtera for providing financial support to the present study.

The study was sponsored by PT Sarihusada Generasi Mahardhika (SGM) and PT Nutricia Indonesia Sejahtera (NIS), but this had no influence on the outcome of the study.

The authors' contributions are as follows: S. M., D. B., R. R., N. A., L. N., L. M., J. B. conceived and designed the study; S. M., D. B., R. R., Z. Z., T. S., L. M. were involved in the execution of the study; and S. M., D. B., R. R., Z. Z., N. A., L. N., T. S., L. M., P. S., J. B. were involved in evaluation of the data and writing of the manuscript. T. S., L. M., P. S., J. B. are employees of SGM, NIS and Nutricia Research, respectively.

None of the authors has any personal or financial conflicts of interest to declare.

\section{References}

1. World Health Organization (2012) Nutrition of women in the preconception period, during pregnancy and the breastfeeding period. Nutrition; report by the Secretariat. http://apps.who.int/ gb/ebwha/pdf_files/WHA65/A65_12-en.pdf (accessed December 2015).

2. Ministry of Health (Indonesia) (2010) Riset Kesehatan Dasar (National Basic Health Research). Jakarta: Badan Penelitian dan Pengembangan Kesehatan, Kementerian Kesehatan RI.

3. Ministry of Health (Indonesia) (2008) Laporan Hasil Riset Kesehatan Dasar (RISKESDAS) Nasional 2007 (National Basic Health Report). Jakarta: Badan Penelitian dan Pengembangan Kesehatan.

4. Hartriyanti H, Suyoto PS, Muhammad HF, et al. (2012) Nutrient intake of pregnant women in Indonesia: a review. Malays $J$ Nutr 18, 113-124.

5. Persson V, Hartini TNS, Greiner T, et al. (2002) Vitamin A intake is low among pregnant women in Central Java, Indonesia. Int J Vitam Nutr Res 72, 124-132.

6. Prihartini S, Jahari AB, Sebayang SK, et al. (2009) Food consumption and anaemia status on pregnant woman sample study SUMMIT (the Supplementation with Multiple Micronutrients Intervention Trial) in Lombok. J Nutr Food Res 32, 37-44.

7. Winkvist A, Stenlund H, Hakimi M, et al. (2002) Weight-gain patterns from pre-pregnancy until delivery among women in Central Java, Indonesia. Am J Clin Nutr 75, 1072-1077.

8. Requejo J, Bryce J, Lawn J, et al. (2010) Countdown to 2015 Decade Report (2000-2010) With Country Profiles: Taking Stock of Maternal, Newborn and Child Survival. Washington, DC: WHO \& UNICEF

9. Badan Pusat Statistik (2010) SUSENAS 2009 Jawa Barat (Indonesian National Social Economic Survey 2009). Bandung: Direktorat Diseminasi Statistik, Subdirektorat Layanan dan Promosi Statistik.

10. Gibson R (2005) Principles of Nutritional Assessment, 2nd ed. New York: Oxford University Press.

11. Sebayang SK, Dibley MJ, Kelly PJ, et al. (2012) Determinants of low birthweight, small-for-gestational-age and preterm birth in Lombok, Indonesia: analyses of the birthweight cohort of the SUMMIT trial. Trop Med Int Health 17, 938-950.

12. Ververs MT, Antierens A, Sackl A, et al. (2013) Which anthropometric indicators identify a pregnant woman as acutely malnourished and predict adverse birth outcomes in the humanitarian context? PLOS Curr, edition 1 (published online 7 June 2013).

13. Ministry of Health (Indonesia) (2004) Daftar Komposisi Bahan Makanan (Food Composition Table). Jakarta: Kementerian Kesehatan RI.

14. Mahmud MK, Zulfianto NA, Apriyantotono RR, et al. (2009) Tabel Komposisi Pangan Indonesia (Table of Indonesia Food Composition). Jakarta: PT Elex Media Komputindo.

15. Southeast Asia Ministers of Education Organisation (2005) NutriSurvey for Windows database, University of Indonesia. http://www.nutrisurvey.de/databases/indones.ZIP

16. Ministry of Health (Indonesia) (2004) Angka Kecukupan Gizi Indonesia (Indonesia Recommended Dietary Allowances). Jakarta: Kementerian Kesehatan RI.

17. Ministry of Health (Indonesia) (1996) 13 Pesan Dasar Gizi Seimbang (13 Messages on Balanced Diets). Jakarta: Direktorat Bina Gizi Kesehatan Keluarga, Kementerian Kesehatan RI.

18. World Health Organization (2001) Iron Deficiency Anaemia Assessment, Prevention, and Control, a Guide for Programme Managers. Geneva: Department of Nutrition for Health and Development \& WHO.

19. Centers for Disease Control and Prevention (2010) Laboratorium Procedure Manual; Ferritin in Serum, NHANES 2009-2010. Atlanta, GA: CDC.

20. World Health Organization (2011) Serum Retinol Concentrations for Determining the Prevalence of Vitamin A Deficiency in Populations. Geneva: Department of Nutrition for Health and Development \& WHO; www.who.int/vmnis/indicators/ retinol.pdf (accessed 24 September).

21. Kruse-Jarres JD, Rükgauer M, Schmitt Y, et al. (1995) Simultane AAS-Bestimmung von Selen und Zink im Blut und seinen zellulären Bestandteilen, demonstriert am Beispiel der oligoanurischen Niereninsuffizienz (Simultaneous AAA analysis of selenium and zinc in blood and its cellular components). Laboratoriumsmedizin 19, 117-127.

22. Cogill B (2003) Anthropometric Indicators Measurement Guide Series Title II Indicators Guide, rev. ed. Washington, DC: Food and Nutrition Technical Assistance Project.

23. Yongky (2007) Analisis Pertambahan Berat Badan ibu Hamil Berdasarkan Status Sosial Ekonomi dan Status Gizi Serta Hubungannya Dengan Berat Bayi Baru Labir (Analysis of Gestational Weight Gain of Pregnant Women by Maternal Socioeconomic and Nutritional Status and its Relationship with Weight of Newborn Infants, Fetal Weight and Length of Birth). Bogor: Institut Pertanian Bogor.

24. Bisai S, Mahalanabis D, Sen A, et al. (2007) Maternal early second trimester pregnancy weight in relation to birth outcome among Bengalee Hindus of Kolkata, India. Ann Hum Biol 34, 91-101.

25. Kerr DA, Schap TE \& Johnson RK (2012) Analysis, presentation and interpretation of dietary data. In Nutrition in the Prevention and Treatment of Disease, 3rd ed. pp. 125-140 [M Ferruzzi, AM Coulston and C Boushy, editors]. Cambridge, MA: Academic Press.

26. Gemming L, Jiang Y, Swinburn B, et al. (2014) Underreporting remains a key limitation of self-reported dietary intake: an analysis of the 2008/09 New Zealand Adult Nutrition Survey. Eur J Clin Nutr 68, 259-264.

27. Litchman SW, Pisarska K, Berman ER, et al. (1992) Discrepancy between self-reported and actual caloric intake and exercise in obese subjects. N Engl J Med 327, 1893-1898.

28. Andersen LT, Thilsted SH, Nielsen BB, et al. (2003) Food and nutrient intakes among pregnant women in rural Tamil Nadu, South India. Public Health Nutr 6, 131-137. 
29. Piirainen $\mathrm{T}$, Isolauri $\mathrm{E}$, Lagström $\mathrm{H}$, et al. (2006) Impact of dietary counselling on nutrient intake during pregnancy: a prospective cohort study. Br J Nutr 96, 1095-1104.

30. Hartini TN, Winkvist A, Lindholm L, et al. (2003) Food patterns during an economic crisis among pregnant women in Purworejo District, Central Java, Indonesia. Food Nutr Bull 24, 256-267.

31. Olsen SF, Halldorsson TI, Willett WC, et al. (2007) Milk consumption during pregnancy is associated with increased infant size at birth: prospective cohort study. Am J Clin Nutr 86, 1104-1110

32. Sartika RA (2011) Effect of trans fatty acids intake on blood lipid profile of workers in East Kalimantan, Indonesia. Malays J Nutr 17, 119-127.

33. Mawaddah N \& Hardinsyah R (2008) Pengetahuan, sikap dan praktek gizi ibu hamil di Kramat Jatidan Ragunan, Propinsi DKI Jakarta (Knowledge, attitude and practice on nutrition among pregnant women in Kramat Jati and Ragunan, DKI Jakarta). J Gizi Pangan 3, 30-42.

34. Michaelsen KF, Hoppe C, Roos N, et al. (2009) Choice of foods and ingredients for moderately malnourished children 6 months to 5 years of age. Food Nutr Bull 30, S343-S404.

35. Hartini TNS, Winkvist A, Lindholm L, et al. (2003) Nutrient intake and iron status of urban poor and rural poor without access to rice fields are affected by the emerging economic crisis: the case of pregnant Indonesian women. Eur J Clin Nutr 57, 654-666.

36. Susilo J \& Hadi H (2002) Hubungan asupan zat besi dan inhibitornya, sebagai prediktor kadar hemoglobin ibu hamil di kabupaten bantul propinsi DIY (Relationship between iron intake and its inhibitor, as prediction of haemoglobin level of pregnant women in Bantul regency, DI Yogyakarta province). Berita Kedokteran Masyarakat 18, 1-8.

37. World Health Organization (2001) Healthy Food and Nutrition for Women and Their Families: Training Course for Health Professionals Part 1: Trainers' Instruction Including Overheads and Handouts. Regional Office for Geneva Central and East Europe the Commonwealth of the Independent States and the Baltics. Copenhagen: WHO Regional Office for Europe.

38. Lee YA, Hwang JY, Kim H, et al. (2011) Relationships of maternal zinc intake from animal foods with fetal growth. BrJ Nutr 106, 237-242.

39. World Health Organization (2004) Vitamin and Mineral Requirements in Human Nutrition, 2nd ed. Geneva: WHO \& FAO. http://www.who.int/nutrition/publications/micronutrients/ 9241546123/en/index.html (accessed December 2015).

40. Hacker AN, Fung EB \& King JC (2012) Role of calcium during pregnancy: maternal and fetal needs. Nutr Rev 70, 397-409.

41. Piammongkol S, Marks GC, Williams G, et al. (2004) Food and nutrient consumption patterns in third trimester Thai-Muslim pregnant women in rural southern Thailand. Asia Pac J Clin Nutr 13, 236-241.

42. Zakiyah S \& Kusmiyati DK (2007) Hubungan antara asupan vitamin A dan asupan seng dengan kejadian anemia pada ibu hamil. Semarang: Diponegoro University.

43. McCrory MA, Hajduk CL \& Roberts SB (2002) Procedures for screening out inaccurate reports of dietary energy intake. Public Health Nutr 5, 873-882. 